\title{
A study on intangible assets disclosure: An evidence from Indian companies
}

\author{
Subhash Chander, Vishakha Mehra \\ Guru Nanak Dev University (India) \\ subh chander@rediffmail.com, mehra.vishakha@gmail.com
}

Received September, 2010

Accepted February, 2011

\section{Abstract}

Purpose: India has emerged at the top of the pedestal in the present knowledge-driven global marketplace, where intangible assets hold much more value than physical assets. The objective of this study is to determine the extent of intangible asset disclosure by companies in India

Design/methodology/approach: This study relates to the years 2003-04 and 2007-08 and is based on 243 companies selected from BT-500 companies. The annual reports of these companies were analyzed using content analysis so as to examine the level of disclosure of intangible asset information. Intangible assets disclosure index based on the intangible assets framework as given by Sveiby (1997) and as used and tested by Guthrie and Petty (2000) and many other subsequent studies was modified and used for this study.

Findings: The results showed that external capital is the most disclosed intangible asset category with a disclosure score of $37.90 \%$ and $35.83 \%$ in the years 2003-04 and 2007-08 respectively. Infosys technologies Ltd. is the company with the highest intangible assets reporting for both the years (2003-04: 68.52\%, 2007-08: 81.48\%). Further the reporting of intangible assets is unorganized and unsystematic. There is lack of appropriate framework for disclosing intangible assets information in the annual reports. 


\section{Intangible Capital}

Intangible Capital, 2011 - 7(1): 1-30 - ISSN: 1697-9818 doi:10.3926/ic.2011.v1n7.p1-30

Originality/value: This is perhaps the first comprehensive study on intangible assets disclosure based on a large sample of the companies from India. Literature reveals that now the intangible assets play relatively an increasingly significant role in the decision making process of various users of corporate reports. This study shows that the overall disclosure of intangible assets is low in India. Thus this study may be of value to the corporate sector in India to explore the areas of intangible assets disclosure so that they can provide useful and relevant information to the users of annual reports.

Keywords: intangible assets, content analysis, extent of disclosure, external capital, internal capital, human capital, reporting.

Jel Codes: $M-41, M-480$

\section{Introduction}

The transition of Indian economy from production to knowledge podium and the growing software \& IT, financial services, business outsourcing, media, healthcare, pharmaceutical industries etc. have lead to increasing investments in intangible assets by the companies. In such knowledge-driven global marketplace, intangible assets such as intellectual property, brands, customer relationship and talent hold much more value than tangible 'visible' assets such as capital, land, buildings, machinery etc. Global Intangible Tracker (GIT) conducted an extensive global study in 2007 on intangibles assets. According to this study, India was ranked third in the world with the highest intangible component as a percentage of the total enterprise value (TEV); measured in terms of value of disclosed and undisclosed tangible and intangible assets (www.sme.in/Currentnews.aspx?NewsID=1832).

The disclosure of such intangible assets is presently restricted in the financial statements under the prevailing reporting practices. Corporate financial reporting needs to evolve to include elements which create value for businesses such as customer satisfaction, brand valuation, business collaborations, corporate culture, etc. The Financial Accounting Standards Board (FASB) also requires that financial reporting should provide information that is useful to present and potential investors and creditors and other users in making rational investment, credit and 
similar decisions. The information on intangibles would certainly improve the quality of such decisions.

\section{Meaning and categories of intangible assets}

The intricate nature of intangible assets makes them difficult to be defined. These can be referred as 'hidden capabilities' of an organization (Edvinsson \& Malone, 1997) or as knowledge based resources that contribute to the creation of a competitive advantage for the firm (Ordóñez de Pablos, 2005). The IFAC (1998) has referred to intellectual capital as "... the total stock of capital or knowledgebased equity that the company possesses." According to the Indian Accounting Standard (AS-26) an intangible assets is an "identifiable non-monetary asset without physical substance held for use in production or supply of goods and services for rental to others, or for administrative purposes." Lev (2001) uses the terms intangible assets, knowledge assets and intellectual capital interchangeably, arguing that they differ only in their discipline of origin- the accountant's intangible assets are knowledge assets for economists and intellectual capital for managers and lawyers.

Though most of the existing literature on intellectual capital equates intellectual capital to intangible assets, but Garcia-Parra et al. (2004) and Garcia-Parra et al. (2009) have refined the concept of intellectual capital. They suggested the existence of intangible liabilities also and hence their inclusion in the concept of intellectual capital. However, the scope of this paper is limited to studying the disclosure of intangible assets only.

Intangible assets of a company can be classified into four main categories-Human resources, External assets, Internal assets and Intellectual property assets. (Meritum, 2000; Guthrie, Petty \& Johanson, 2001; Vergauwen \& Alem, 2005)

\section{Human resources}

Human resources represent the individual knowledge stock of an organization as represented by its employees (Bontis, Crossan \& Hulland, 2002). It is the single most important and powerful factor that differentiates one organization from another. It consists of specific individuals who cannot be owned by the company, nor can it be copied by any of its competitors. When a company invests in human 
capital, it increases its own value, gaining a sustainable long-run competitive advantage.

\section{External assets}

This intangible assets category represents relationship of a company with its customers, suppliers, business partners, industry associates, market channels, investors, society etc. External assets are the market related intangibles that enhance the fitness of an organization for succeeding in the marketplace.

\section{Internal assets}

Internal assets are systems, routines, technologies, databases, methodologies, processes and culture that are idiosyncratic to an organization. It comprises the capabilities of a company, its infrastructure and organizational processes to manufacture products and render services to the market. Intangible assets of this category constantly need to adapt to changing business scenarios. These assets give the organization a unique advantage over its competitors as these assets are not licensed to outsiders and are under company's control.

\section{Intellectual property assets}

Intellectual property assets include know-how, copyrights, patents, products and tools that are owned by a corporation. These assets are valued based on their commercial potential. A corporation can derive its revenues from licensing these assets to outside users.

\section{Review of literature}

Intangible assets have become an integral part of value-creating process for any company. This necessitates its external communication to various interested parties like shareholders, investors etc. Several studies have been conducted in different parts of the world to examine the extent of intangible assets reporting. A snapshot of these studies is given in table 1 : 


\begin{tabular}{|c|c|c|c|c|c|}
\hline $\begin{array}{l}\text { Author/ } \\
\text { Year }\end{array}$ & $\begin{array}{l}\text { Sample } \\
\text { Size/ } \\
\text { Country }\end{array}$ & $\begin{array}{l}\text { Methodology } \\
\text { : Manual } \\
\text { Content } \\
\text { Analysis } \\
\text { (CA) or } \\
\text { Automated } \\
\text { Word search } \\
\text { (WS) }\end{array}$ & $\begin{array}{l}\text { Basis of } \\
\text { intangible } \\
\text { assets } \\
\text { framework } \\
\text { used }\end{array}$ & $\begin{array}{l}\text { No. of } \\
\text { disclosure } \\
\text { items in } \\
\text { intangible } \\
\text { assets } \\
\text { index }\end{array}$ & Findings \\
\hline $\begin{array}{l}\text { Guthrie \& } \\
\text { Petty (2000) }\end{array}$ & $\begin{array}{l}20 \\
\text { (Australia) }\end{array}$ & CA & $\begin{array}{l}\text { Sveiby } \\
\text { (1997) }\end{array}$ & 24 & $\begin{array}{l}\text { External capital is } \\
\text { most reported } \\
\text { intangible assets } \\
\text { category }\end{array}$ \\
\hline $\begin{array}{l}\text { Brennan } \\
\text { (2001) }\end{array}$ & $\begin{array}{l}11 \\
\text { (Ireland) }\end{array}$ & $C A$ & $\begin{array}{l}\text { Sveiby } \\
(1997)\end{array}$ & 24 & $\begin{array}{l}\text { External capital is } \\
\text { most reported } \\
\text { intangible assets } \\
\text { category }\end{array}$ \\
\hline $\begin{array}{l}\text { Bozzolan et } \\
\text { al (2003) }\end{array}$ & $\begin{array}{l}30 \\
\text { (Italy) }\end{array}$ & $\mathrm{CA}$ & $\begin{array}{l}\text { Sveiby } \\
\text { (1997) }\end{array}$ & 22 & $\begin{array}{l}\text { External capital is } \\
\text { most reported } \\
\text { intangible assets } \\
\text { category }\end{array}$ \\
\hline $\begin{array}{l}\text { April et al } \\
\text { (2003) }\end{array}$ & $\begin{array}{l}20 \\
\text { (South } \\
\text { Africa) }\end{array}$ & $\mathrm{CA}$ & $\begin{array}{l}\text { Sveiby } \\
\text { (1997) }\end{array}$ & 24 & $\begin{array}{l}\text { External capital is } \\
\text { most reported } \\
\text { intangible assets } \\
\text { category }\end{array}$ \\
\hline $\begin{array}{l}\text { Bontis } \\
(2003)\end{array}$ & $\begin{array}{l}10000 \\
\text { (Canada) }\end{array}$ & WS & $\begin{array}{l}\text { Panel of } \\
\text { researchers } \\
\text { from world } \\
\text { congress }\end{array}$ & 39 & $\begin{array}{l}\text { Overall disclosure of } \\
\text { intangible assets is } \\
\text { very low }\end{array}$ \\
\hline $\begin{array}{l}\text { Goh \& Lim } \\
(2004)\end{array}$ & $\begin{array}{l}20 \\
\text { (Malaysia) }\end{array}$ & $C A$ & $\begin{array}{l}\text { Sveiby } \\
(1997)\end{array}$ & 24 & $\begin{array}{l}\text { External capital is } \\
\text { most reported } \\
\text { intangible assets } \\
\text { category }\end{array}$ \\
\hline $\begin{array}{l}\text { Wong \& } \\
\text { Gardner } \\
(2004)\end{array}$ & $\begin{array}{l}60 \\
\text { (New } \\
\text { Zealand) }\end{array}$ & $\mathrm{CA}$ & $\begin{array}{l}\text { Sveiby } \\
\text { (1997) }\end{array}$ & 18 & $\begin{array}{l}\text { External capital is } \\
\text { most reported } \\
\text { intangible assets } \\
\text { category }\end{array}$ \\
\hline $\begin{array}{l}\text { Abeysekera } \\
\text { \& Guthrie } \\
(2005)\end{array}$ & $\begin{array}{l}30 \\
\text { (Sri Lanka) }\end{array}$ & $C A$ & $\begin{array}{l}\text { Sveiby } \\
\text { (1997) }\end{array}$ & 45 & $\begin{array}{l}\text { External capital is } \\
\text { most reported } \\
\text { intangible assets } \\
\text { category }\end{array}$ \\
\hline $\begin{array}{l}\text { Oliveras \& } \\
\text { Kasperskaya } \\
(2005)\end{array}$ & $\begin{array}{l}14 \\
\text { (Spain) }\end{array}$ & CA & $\begin{array}{l}\text { Sveiby } \\
\text { (1997) }\end{array}$ & 25 & $\begin{array}{l}\text { External capital is } \\
\text { most reported } \\
\text { intangible assets } \\
\text { category }\end{array}$ \\
\hline $\begin{array}{l}\text { Oliveira et al } \\
(2006)\end{array}$ & $\begin{array}{l}56 \\
\text { (Portugal) }\end{array}$ & $C A$ & $\begin{array}{l}\text { Self- } \\
\text { generated } \\
\text { index }\end{array}$ & 31 & $\begin{array}{l}\text { External capital is } \\
\text { most reported } \\
\text { intangible assets } \\
\text { category }\end{array}$ \\
\hline $\begin{array}{l}\text { Sujan \& } \\
\text { Abeysekera } \\
(2007)\end{array}$ & $\begin{array}{l}20 \\
\text { (Australia) }\end{array}$ & CA & $\begin{array}{l}\text { Sveiby } \\
\text { (1997) }\end{array}$ & 25 & $\begin{array}{l}\text { External capital is } \\
\text { most reported } \\
\text { intangible assets } \\
\text { category }\end{array}$ \\
\hline $\begin{array}{l}\text { Steenkamp } \\
\text { (2007) }\end{array}$ & $\begin{array}{l}30 \\
\text { (New } \\
\text { Zealand) }\end{array}$ & CA & $\begin{array}{l}\text { Sveiby } \\
\text { (1997) }\end{array}$ & 17 & $\begin{array}{l}\text { Human capital is } \\
\text { most reported } \\
\text { intangible assets } \\
\text { category }\end{array}$ \\
\hline $\begin{array}{l}\text { Gerpott et al } \\
(2008)\end{array}$ & $\begin{array}{l}29 \\
\text { (Multi- } \\
\text { country) }\end{array}$ & $C A$ & $\begin{array}{l}\text { Edvinsson \& } \\
\text { Malone } \\
\text { (1997) } \\
\text { skandia } \\
\text { value } \\
\text { scheme }\end{array}$ & 7 & $\begin{array}{l}\text { Low disclosure of } \\
\text { intangible assets } \\
\text { that too in } \\
\text { qualitative form }\end{array}$ \\
\hline
\end{tabular}




\begin{tabular}{|l|l|l|l|l|l|}
\hline $\begin{array}{l}\text { Author/ } \\
\text { Year }\end{array}$ & $\begin{array}{l}\text { Sample } \\
\text { Size/ } \\
\text { Country }\end{array}$ & $\begin{array}{l}\text { Methodology } \\
\text { Manual } \\
\text { Content } \\
\text { Analysis } \\
\text { (CA) or } \\
\text { Automated } \\
\text { Word search } \\
\text { (WS) }\end{array}$ & $\begin{array}{l}\text { Basis of } \\
\text { intangible } \\
\text { assets } \\
\text { framework } \\
\text { used }\end{array}$ & $\begin{array}{l}\text { No. of } \\
\text { disclosure } \\
\text { items in } \\
\text { intangible } \\
\text { assets } \\
\text { index }\end{array}$ & Findings \\
\hline $\begin{array}{l}\text { Ali et al } \\
(2008)\end{array}$ & $\begin{array}{l}22 \\
\text { (Bangladesh) }\end{array}$ & CA & $\begin{array}{l}\text { Sveiby } \\
(1997)\end{array}$ & 27 & $\begin{array}{l}\text { Internal capital is } \\
\text { most reported } \\
\text { intangible assets } \\
\text { category }\end{array}$ \\
\hline $\begin{array}{l}\text { Kamath } \\
(2008)\end{array}$ & $\begin{array}{l}30 \\
\text { (India) }\end{array}$ & WS & $\begin{array}{l}\text { Bontis } \\
(2003)\end{array}$ & 39 & $\begin{array}{l}\text { Overall disclosure of } \\
\text { intangible assets is } \\
\text { very low }\end{array}$ \\
\hline $\begin{array}{l}\text { Woodrock \& } \\
\text { Whiting } \\
\text { (2009) }\end{array}$ & $\begin{array}{l}70 \\
\text { (Australia) }\end{array}$ & CA & $\begin{array}{l}\text { Sveiby } \\
\text { (1997) } \\
\text { most reported } \\
\text { intangible assets } \\
\text { category }\end{array}$ \\
\hline
\end{tabular}

Table 1. Empirical studies on the extent of Intangible assets Disclosure.

The review of the above studies shows that for all the studies except one (Bontis, 2003), the sample size has been less than or equal to 70. Guthrie and Petty (2000) pioneered the use of Sveiby's intellectual capital framework to determine the extent of disclosure. Brennan (2001), Bozzolan et al. (2003), April et al. (2003), Goh and Lim (2004), Abeysekera and Guthrie (2005), Oliveras and Kasperskaya (2005), Sujan and Abeysekera (2007), Woodrock and Whiting (2009) followed him by using similar framework. In addition, despite differing in firm selection criteria and measurement unit in the content analysis, the studies from Australia (Guthrie \& Petty, 2000; Woodrock \& Whiting, 2009 ); Ireland (Brennan, 2001); Italy (Bozzolan et al, 2003); South Africa (April et al, 2003); Malaysia (Goh \& Lim, 2004); Sri Lanka (Abeysekera \& Guthrie, 2005); Spain (Oliveras \& Kasperskaya, 2005); New Zealand (Wong \& Gardner, 2004) consistently showed that external capital was the most frequently reported intangible assets category. Most of the researchers have found disclosures to be low and that too in qualitative form except since 2007, after which shift towards quantitative and high disclosures has been noticed (Sujan \& Abeysekera, 2007; Steenkamp, 2007).

\section{Objective of the study}

The review of literature shows that a number of studies have been conducted all over the world on disclosure of voluntary information on intangible assets by the companies. However, to the best of the knowledge of researchers only one study 


\section{Intangible Capital}

Intangible Capital, $2011-7(1): 1-30$ - ISSN: 1697-9818 doi:10.3926/ic.2011.v1n7.p1-30 by Kamath (2008) has been conducted in India. Kamath's study also suffers from certain limitations like small sample size of only 30 companies from few specific industries and word count technique used for data collection. The dearth of literature on the subject in the Indian context and the ever increasing significance of intangible assets in the Indian corporate sector motivated the researchers to carry out this study. Accordingly the objective of this study is to determine the extent of intangible asset disclosure by Indian companies for the year 2003-04 and 2007-08. The reason for selecting years 2003-04 and 2007-08 is that the year 2003-04 was the first year for the mandatory application of Accounting Standard26 on intangible assets and 2007-08 was the recent year and the availability of annual reports was easier.

\section{Database and research methodology}

\section{Universe of the study and sample selection}

BT-500 private sector companies rated on the basis of their market capitalization constitute the universe of this study (BT-500 companies, Business Today, Special issue- November 29, 2007). The following filters were applied to select the sample:

- The companies whose annual reports were not available for the years 200304 and 2007-08 were not considered.

- The companies whose financial year ends other than on March 31 and December 31, 2004 and 2008 were also eliminated.

Thus, as a result of these filters, a sample of 243 companies was selected and studied for the years 2003-04 and 2007-08 to measure the extent of intangible assets disclosure.

\section{Data source}

The source of data is annual reports. Annual reports are considered to be most widely distributed and regularly produced document which influence investors' decisions. Annual reports of the companies were retrieved from their respective websites. EDIFAR dataset of annual reports set out by SEBI was also used as a source of data collection. 


\section{Collection of data}

To measure the level of intangible assets disclosure for the sample companies, content analysis was performed on their annual reports. Content analysis as a technique for gathering data, involves codifying qualitative and quantitative information into pre-defined categories in order to derive patterns in the presentation and reporting of information (Guthrie et al, 2004). For this study content analysis of the annual reports of each of the 243 companies selected in a sample involved the following steps:

- Preparation of Intangible assets disclosure index based on the Intangible assets Framework as given by Sveiby (1997) and as used and tested by Guthrie and Petty (2000) and many other subsequent studies which followed Guthrie and Petty framework. It was modified in Indian context. It comprises of 29 attributes in five main categories (Appendix A).

- Reading the annual report to find out the disclosure of intangible assets information reported by a company.

- Some of the decision rules used for highlighting and classification of intangible assets information are:

- Sentences were used as recording unit since they are viewed to be the most reliable and complete unit of analysis (Milne \& Adler, 1999);

- Content analysis was performed on entire annual report;

- If reporting of the same attribute was repeated in the annual report it was recorded only once;

- Some concepts are broad so their meaning was scored rather than use of exact words; and

- Each attribute of disclosure has been considered equally important. This is because the focus of study is not on any particular user group rather on all the users of corporate annual reports.

The intangible assets information was assigned scores ( 0 or 1 or 2 ) on the basis of its qualitative or quantitative nature which is given in table 2 below. Past research 
shows that the same scoring technique has been used in studies from Australia (Guthrie \& Petty, 2000), Italy (Bozzolan et al, 2003), Spain (Meca \& Martinez, 2005), Portugal (Oliveira et al, 2006), Australia (Sujan \& Abeysekera, 2007; Woodrock \& Whiting, 2009), Bangladesh (Ali et al, 2008). The heavier weighting given to quantitative disclosures is based on the assertion that precise information is more useful and will enhance management's reputation and credibility (Botosan, 1997).

\begin{tabular}{|l|c|}
\hline \multicolumn{1}{|c|}{ Information Category } & Score Assigned \\
\hline Information in quantitative form & 2 \\
\hline Information in qualitative form & 1 \\
\hline No information & 0 \\
\hline
\end{tabular}

Table 2. Scoring of various attributes of Intangible Assets.

The above scoring technique has been used for all attributes in all categories except for first four attributes in Mandatory Disclosure Requirement category, whereby a score of ' 1 ' has been given if the disclosure requirement is fulfilled and a score of ' $O$ ' is given if the requirement was not satisfied. This is because these attributes are all qualitative and only their presence or absence has been studied in the annual reports.

\section{Analysis and discussion}

The results of the study have been discussed in two parts. Part I discusses the attribute-wise disclosure, category-wise disclosure and nature of disclosure. Part II deals with the company-wise disclosure of intangible assets information presented in the annual reports of selected sample companies in India for both the years of the study.

\section{Part:I Attribute-wise disclosure in annual reports}

This section explains the attribute-wise analysis for each and every category of intangible assets disclosure index. Table 3 presents the attribute-wise disclosure both in absolute figures as well as in percentages for the years 2003-04 and 200708 respectively. The attribute-wise disclosure score has been calculated for each attribute included in the intangible assets disclosure index, by dividing the total weighted disclosure score attained for that attribute with the maximum weighted disclosure score. 
9 Intangible Capital

Intangible Capital, 2011 - 7(1): 1-30 - ISSN: 1697-9818

doi:10.3926/ic.2011.v1n7.p1-30

\begin{tabular}{|c|c|c|c|c|c|}
\hline \multirow[b]{2}{*}{ ATTRIBUTES } & \multicolumn{2}{|c|}{ 2003-04 } & \multicolumn{2}{|c|}{ 2007-08 } & \multirow{2}{*}{$\begin{array}{l}\text { Percentage } \\
\text { change in } \\
\text { disclosure } \\
\text { score in } \\
\text { year } 2007 \text { - } \\
08 \text { over } \\
2003-04 \\
\end{array}$} \\
\hline & $\begin{array}{l}\text { Weighted } \\
\text { Disclosure } \\
\text { score }\end{array}$ & $\begin{array}{c}\% \\
\text { Disclosure }\end{array}$ & $\begin{array}{l}\text { Weighted } \\
\text { Disclosure } \\
\text { score }\end{array}$ & $\begin{array}{c}\% \\
\text { Disclosure }\end{array}$ & \\
\hline \multicolumn{6}{|l|}{ HUMAN CAPITAL } \\
\hline \multicolumn{6}{|l|}{ Employees } \\
\hline -Number & 294 & 60.49 & 346 & 71.19 & 17.69 \\
\hline -Gender & 2 & 0.41 & 10 & 2.06 & 400.00 \\
\hline $\begin{array}{l}\text {-Professional Qualification } \\
\text { and Experience }\end{array}$ & 149 & 30.66 & 207 & 42.59 & 38.93 \\
\hline -Compensation & 155 & 31.89 & 203 & 41.77 & 30.97 \\
\hline Training and development & 128 & 26.34 & 188 & 38.68 & 46.88 \\
\hline Work related knowledge & 4 & 0.82 & 9 & 1.85 & 125.00 \\
\hline Entrepreneurial Spirit & 1 & 0.21 & 12 & 2.47 & 1100.00 \\
\hline $\begin{array}{l}\text { Human resource } \\
\text { accounting }\end{array}$ & 6 & 1.23 & 6 & 1.23 & 0.00 \\
\hline \multicolumn{6}{|l|}{ EXTERNAL CAPITAL } \\
\hline $\begin{array}{l}\text { Brands and their } \\
\text { description }\end{array}$ & 149 & 30.66 & 215 & 44.24 & 44.30 \\
\hline Brand valuation & 6 & 1.23 & 6 & 1.23 & 0.00 \\
\hline Distribution channels & 132 & 27.16 & 205 & 42.18 & 55.30 \\
\hline Market share, markets & 235 & 48.35 & 291 & 59.88 & 23.83 \\
\hline Business collaboration & 163 & 33.54 & 228 & 46.91 & 39.88 \\
\hline Customer satisfaction & 27 & 5.56 & 41 & 8.44 & 51.85 \\
\hline $\begin{array}{l}\text { Customer information } \\
\text { (no.) }\end{array}$ & 84 & 17.28 & 130 & 26.75 & 54.76 \\
\hline Social Activities & 141 & 29.01 & 205 & 42.18 & 45.39 \\
\hline \multicolumn{6}{|l|}{ INTERNAL CAPITAL } \\
\hline Research projects & 268 & 55.14 & 312 & 64.20 & 16.42 \\
\hline $\begin{array}{l}\text { Networking and } \\
\text { information } \\
\text { systems }\end{array}$ & 27 & 5.56 & 77 & 15.84 & 185.19 \\
\hline Organization Structure & 11 & 2.26 & 28 & 5.76 & 154.55 \\
\hline Corporate culture & 49 & 10.08 & 110 & 22.63 & 124.49 \\
\hline Patents & 53 & 10.91 & 83 & 17.08 & 56.60 \\
\hline Copyrights & 4 & 0.82 & 7 & 1.44 & 75.00 \\
\hline Trademarks & 7 & 1.44 & 34 & 7.00 & 385.71 \\
\hline $\begin{array}{l}\text { INTANGIBLE ASSETS } \\
\text { SCORESHEET }\end{array}$ & 6 & 1.23 & 6 & 1.23 & 0.00 \\
\hline \multicolumn{6}{|l|}{$\begin{array}{l}\text { MANDATORY } \\
\text { DISCLOSURE } \\
\text { REQUIREMENT }\end{array}$} \\
\hline $\begin{array}{l}\text { Distinction between } \\
\text { internally generated and } \\
\text { other intangible assets }\end{array}$ & 6 & 2.47 & 21 & 8.64 & 250.00 \\
\hline
\end{tabular}

A study on intangible assets disclosure: An evidence from Indian companies 


\begin{tabular}{|c|c|c|c|c|c|}
\hline \multirow[b]{2}{*}{ ATTRIBUTES } & \multicolumn{2}{|c|}{ 2003-04 } & \multicolumn{2}{|c|}{ 2007-08 } & \multirow{2}{*}{$\begin{array}{c}\text { Percentage } \\
\text { change in } \\
\text { disclosure } \\
\text { score in } \\
\text { year } 2007- \\
08 \text { over } \\
2003-04 \\
\end{array}$} \\
\hline & $\begin{array}{l}\text { Weighted } \\
\text { Disclosure } \\
\text { score }\end{array}$ & $\begin{array}{c}\% \\
\text { Disclosure }\end{array}$ & $\begin{array}{l}\text { Weighted } \\
\text { Disclosure } \\
\text { score }\end{array}$ & $\begin{array}{c}\% \\
\text { Disclosure }\end{array}$ & \\
\hline $\begin{array}{l}\text { Details of amortization } \\
\text { rates, method and } \\
\text { carrying amount at } \\
\text { beginning and end of } \\
\text { period }\end{array}$ & 92 & 37.86 & 177 & 72.84 & 90.22 \\
\hline $\begin{array}{l}\text { Classification of intangible } \\
\text { assets }\end{array}$ & 87 & 35.80 & 170 & 69.96 & 95.40 \\
\hline $\begin{array}{l}\text { Other disclosures like } \\
\text { pledging information, } \\
\text { reasons for amortizing } \\
\text { over more than } 10 \text { years } \\
\text { etc }\end{array}$ & 2 & 0.82 & 7 & 2.88 & 250.00 \\
\hline $\begin{array}{l}\text { Intangible assets } \\
\text { Valuation }\end{array}$ & 184 & 37.86 & 354 & 72.84 & 92.39 \\
\hline
\end{tabular}

Table 3. Attribute Wise Disclosure of Intangible Assets.

A brief look of the table 3 shows that disclosure score in the year 2007-08 over the year 2003-04 has improved for all attributes except three attributes for which it remained constant. There is also significant change in the percentage disclosure score in the year 2007-08 as compared to the year 2003-04. The attribute-wise disclosure for each category has been analyzed in details in the following paragraphs.

\section{Human capital}

Number of employees is the most reported attribute in the category of human resources. It has highest weighted disclosure score of $60.49 \%$ in $2003-04$ and $71.19 \%$ in 2007-08. The disclosure on number of employees is an indication of the size of an organization and aids in analyzing the change in its operations. Disclosure regarding the attribute Professional qualification and experience is $30.66 \%$ in $2003-04$ and $42.59 \%$ in $2007-08$. These people-based skills are essential for operations and success of any organization. They also depict quality of employees working in an organization. Disclosing information relating to educational qualification of employees may signal to investors about high calibre management staff in the company and superior hiring policies. Further the present study reveals least reporting regarding gender attribute. Disclosure score is $0.41 \%$ and $2.06 \%$ for 2003-04 and 2007-08 respectively. This information is vital as businesses are consistently recognizing that a higher percentage of professional women in an organization translate into a more innovative workforce. Companies 
acknowledge the valuable contributions made by women at different managerial roles due to their innate skill sets. Work related knowledge and entrepreneurial spirit are eminent intangible assets attributes to contribute towards value-creation in business and thus the wealth of investors. However these attributes have hardly been reported by companies for both the years of study. Information in the annual reports, regarding problem-solving approach, risk-taking attitude, client handling techniques, innovative abilities of employees helps investors in judging the strengths of an organization.

\section{External capital}

Within the external capital category, the attribute Markets/Market Share is the most frequently reported attribute for both the years of the study. Disclosure regarding this attribute is $48.35 \%$ in $2003-04$ which increased to $59.88 \%$ in 2007 08.The high disclosure could be due to the fact that information regarding this attribute is usually collected by company's marketing department. Thus, the marginal cost of preparing these data for external reporting purposes is low. Business collaborations is the second most reported intangible assets attribute in this category, for both the years of study. The importance placed to business collaborations is not surprising as mutual alliances and other forms of collaborative arrangements, of an organization with its industry associates or strategic partners, are becoming common way of conducting business and implementing growth strategies. Business collaboration is the top-scoring attribute in similar researches by Guthrie et al. (2006), Sujan and Abeysekera (2007) and Woodrock and Whiting (2009). Brand valuation is a tool employed by companies to manage their brands in order to deliver optimal and sustainable value to its stakeholders. Investors nowadays prefer greater understanding and disclosure of brand valuation and marketing performance information to improve their investment decisions. Despite the significance of its communication externally, only Infosys Technologies Ltd. and Satyam Computer Services Ltd. (now Mahindra Satyam) from software industry and Alembic Ltd. from pharmaceutical industry have disclosed their brand valuation information in their annual reports for the years 2003-04 and 2007-08 respectively. Low disclosures regarding brand valuation in annual reports could be inferred from the fact that companies yet do not realize the significance of brand value in determining its true overall value. The other reason could be that the companies might be reluctant to share this information with their stakeholders because of their brand value being low. 
Internal capital

Research Activities is the most disclosed attribute in internal capital category for both the years of study (55.14\% in 2003-04 and $64.20 \%$ in 2007-08). These activities represent lifeblood for any organization and help in boosting sales, increasing profitability, opening new markets, attracting best employees, finding new business partners, attracting external finance etc. Corporate culture is the second most reported attribute in internal capital category for the year 2007-08. It refers to the combined beliefs, values, ethics, procedures, and atmosphere of an organization. Intangible assets like organization culture are hard for competitors to replicate. This internal capital attribute has mostly been reported in qualitative form in the annual reports. It has $10.08 \%$ disclosure in 2003-04 and $22.63 \%$ disclosure in 2007-08. Other intellectual capital attributes in internal capital category are patents, copyrights and trademarks. Patents have voluntary disclosure score of $10.91 \%$ in 2003-04 and $17.08 \%$ in 2007-08. Likewise copyrights have low disclosure score of $0.82 \%$ in 2003-04 which increased to $1.44 \%$ in 2007-08 and trademarks too have little disclosure score of $1.44 \%$ in 2003-04 followed by $7.00 \%$ in 2007-08.

\section{Intangible assets scoresheet}

Intangible assets Scoresheet has been disclosed only in annual reports of Infosys Technologies Ltd., Satyam Computer Services Ltd. and Infotech Enterprises Ltd. for both the years. The intangible assets scoresheet provided by these companies clearly points out the company's intangible assets and their growth, by giving a comparative picture over the years. It has been presented as additional information to the investors. These companies strongly believe that the intangible assets scoresheet provides a tool to the investors for evaluating their market worthiness. However lack of awareness among corporates regarding the importance of intangible assets scoresheet in determining the true value of their company could have resulted in its meager disclosure.

\section{Mandatory disclosure requirement}

Accounting Standard 26 on Intangible assets issued by the Institute of Chartered Accountants of India in 2002 specifies some disclosure requirements for companies having intangible assets in their balance sheets. These requirements have been categorized into four sub-heads. 


\section{Intangible Capital}

Intangible Capital, 2011 - 7(1): 1-30 - ISSN: 1697-9818 doi:10.3926/ic.2011.v1n7.p1-30

The first sub-head i.e. distinction between internally generated and other intangible assets, has a disclosure score of $2.47 \%$ in the year $2003-04$ and $8.64 \%$ in the year 2007-08. Low disclosure score for both the years shows that not many companies, which have intangible assets in their books, are differentiating between internally generated and acquired intangible assets. AS-26 also requires that companies should give details of amortization rates, method and carrying amount at beginning and end of period. Disclosure score for this sub-head is $37.86 \%$ in $2003-04$ and $72.84 \%$ in $2007-08$.

Classification of intangible assets into separate classes is also one of the requisites of AS-26. For the year 2003-04, out of $37.86 \%$ companies having intangible assets in their balance sheet, $35.80 \%$ companies are categorizing them into classes like software, brand, licenses etc. Similarly for the year 2007-08, 69.96\% companies are categorizing their intangible assets, out of a total of $72.84 \%$ of sample companies which recognize intangible assets in their books of accounts.

Other disclosures like pledging information, reasons for amortizing over more than 10 years etc. have achieved a score of $0.82 \%$ in $2003-04$ and $2.88 \%$ in 2007-08. Low disclosure for this sub-head could be due to limited applicability of this disclosure requirement.

In India there is an increasing awareness among corporates to disclose and value their intangible assets. Intangible assets valuation means assigning a fair monetary value to intangible assets (whether internally generated or acquired from outside) in a company. Accordingly, this category has received a disclosure score of $37.86 \%$ in 2003-04 and $72.84 \%$ in 2007-08.

\section{Nature of intangible assets disclosure}

After explaining in detail the extent of disclosure it is very essential to discuss about the nature of reporting of intangible assets as well. Nature of intangible assets disclosure involves distinguishing between qualitative and quantitative nature of reporting. The percentage number of companies as mentioned in the table 4 has been calculated by dividing the total number of companies disclosing an attribute in qualitative or quantitative form by total number of sample companies (which is 243). For example training and development attribute for the year 200304 has been disclosed by $20.58 \%$ companies in qualitative form and $16.05 \%$ in 
Intangible Capital

Intangible Capital, 2011 - 7(1): 1-30 - ISSN: 1697-9818

doi:10.3926/ic.2011.v1n7.p1-30

quantitative form. Table 4 depicts the nature of intangible assets disclosure in annual reports for both years of the study.

\begin{tabular}{|c|c|c|c|c|}
\hline \multirow{3}{*}{ Attributes } & \multicolumn{4}{|c|}{ Number of companies (in percent) } \\
\hline & \multicolumn{2}{|c|}{ 2003-04 } & \multicolumn{2}{|c|}{$2007-08$} \\
\hline & $\begin{array}{l}\text { Qualitative } \\
\text { Disclosure } \\
\end{array}$ & $\begin{array}{c}\text { Quantitative } \\
\text { Disclosure }\end{array}$ & $\begin{array}{l}\text { Qualitative } \\
\text { Disclosure } \\
\end{array}$ & $\begin{array}{c}\text { Quantitative } \\
\text { Disclosure }\end{array}$ \\
\hline \multicolumn{5}{|l|}{ HUMAN CAPITAL } \\
\hline \multicolumn{5}{|l|}{ Employees } \\
\hline -Number & 0.00 & 60.49 & 2.47 & 69.96 \\
\hline -Gender & 0.82 & 0.00 & 1.65 & 1.23 \\
\hline $\begin{array}{l}\text {-Professional qualification and } \\
\text { Experience }\end{array}$ & 20.16 & 20.58 & 7.00 & 39.09 \\
\hline -Compensation & 21.81 & 20.99 & 8.64 & 37.45 \\
\hline Training \& Development & 20.58 & 16.05 & 39.51 & 18.93 \\
\hline Work related knowledge & 0.00 & 0.82 & 2.88 & 0.41 \\
\hline Entrepreneurial Spirit & 0.41 & 0.00 & 4.12 & 0.41 \\
\hline Human resource accounting & 0.00 & 1.23 & 0.00 & 1.23 \\
\hline \multicolumn{5}{|l|}{ EXTERNAL CAPITAL } \\
\hline Brands and their specification & 25.10 & 18.11 & 26.75 & 30.86 \\
\hline Brand valuation & 0.00 & 1.23 & 0.00 & 1.23 \\
\hline Distribution channels & 18.93 & 17.70 & 29.22 & 27.57 \\
\hline Market share, markets & 31.69 & 32.51 & 34.16 & 42.80 \\
\hline Business collaboration & 15.23 & 25.93 & 19.75 & 37.04 \\
\hline Customer satisfaction & 2.88 & 4.12 & 10.29 & 3.29 \\
\hline Customer information (no.) & 4.94 & 14.81 & 7.41 & 23.05 \\
\hline Social Activities & 21.81 & 18.11 & 23.46 & 30.45 \\
\hline \multicolumn{5}{|l|}{ INTERNAL CAPITAL } \\
\hline Research projects & 11.52 & 49.38 & 12.35 & 58.02 \\
\hline $\begin{array}{l}\text { Networking and information } \\
\text { systems }\end{array}$ & 8.64 & 1.23 & 20.99 & 5.35 \\
\hline Organization Structure & 1.23 & 1.65 & 4.12 & 3.70 \\
\hline Corporate culture & 19.34 & 0.41 & 43.62 & 0.82 \\
\hline Patents & 4.53 & 8.64 & 2.88 & 15.64 \\
\hline Copyrights & 0.82 & 0.41 & 1.23 & 0.82 \\
\hline Trademarks & 1.23 & 0.82 & 2.47 & 5.76 \\
\hline $\begin{array}{l}\text { INTANGIBLE ASSETS } \\
\text { SCORESHEET }\end{array}$ & 0.00 & 1.23 & 0.00 & 1.23 \\
\hline
\end{tabular}

A study on intangible assets disclosure: An evidence from Indian companies 


\begin{tabular}{|c|c|c|c|c|}
\hline \multirow{3}{*}{ Attributes } & \multicolumn{4}{|c|}{ Number of companies (in percent) } \\
\hline & \multicolumn{2}{|c|}{ 2003-04 } & \multicolumn{2}{|c|}{ 2007-08 } \\
\hline & $\begin{array}{l}\text { Qualitative } \\
\text { Disclosure } \\
\end{array}$ & $\begin{array}{c}\text { Quantitative } \\
\text { Disclosure }\end{array}$ & $\begin{array}{l}\text { Qualitative } \\
\text { Disclosure } \\
\end{array}$ & $\begin{array}{c}\text { Quantitative } \\
\text { Disclosure }\end{array}$ \\
\hline $\begin{array}{l}\text { MANDATORY DISCLOSURE } \\
\text { REQUIREMENTS }\end{array}$ & & & & \\
\hline $\begin{array}{l}\text { Distinction between internally } \\
\text { generated and other intangible } \\
\text { assets }\end{array}$ & 2.88 & N.A. & 8.64 & N.A. \\
\hline $\begin{array}{l}\text { Details of amortization rates, } \\
\text { method and carrying amount at } \\
\text { beginning and end of period }\end{array}$ & 38.27 & N.A. & 72.84 & N.A. \\
\hline Classification of intangible assets & 36.21 & N.A. & 69.96 & N.A. \\
\hline $\begin{array}{l}\text { Other disclosures like pledging } \\
\text { information, reasons for amortizing } \\
\text { over more than } 10 \text { years etc }\end{array}$ & 1.23 & N.A. & 2.88 & N.A. \\
\hline Intangible assets valuation & 0.00 & 38.27 & 0.00 & 72.84 \\
\hline
\end{tabular}

Table 4. Nature of intangible assets disclosure.

Table 4 illustrates that nature of disclosures (both qualitative and quantitative) has improved in the year 2007-08 as compared to the year 2003-04. For Number of employees attribute in human capital category, $60.49 \%$ companies were disclosing in quantitative form in the year 2003-04 which increased to $69.96 \%$ in 2007-08. Similarly in context of professional qualification and experience of employees, $20.16 \%$ were reporting in qualitative form and $20.58 \%$ in quantitative form in the year 2003-04. In the year 2007-08, companies reporting in qualitative form remained only $7 \%$ and it seems they shifted to quantitative disclosures (39.09\%). In external capital category, the attribute brands and its specification is reported by $25.10 \%$ companies in qualitative form and $18.11 \%$ companies in quantitative form in the year 2003-04. These numbers increased to $26.75 \%$ and $30.86 \%$ respectively in the year 2007-08. Information concerning distribution channels which is reported by $17.70 \%$ companies in quantitative form in year 2003-04, increased to $27.57 \%$ companies in 2007-08. Improved disclosures can be noticed for all the attributes of internal capital. For the corporate culture attribute majority of the companies are reporting this attribute in qualitative form. Difficulty in its quantification could have motivated for its reporting mainly in narrative form. Intangible assets valuation information has been provided by almost double the number of companies in 2007-08 as compared to year 2003-04. While $38.27 \%$ companies were valuing its intangibles in year 2003-04, it increased to $72.84 \%$ companies in the year 2007-08. 


\section{Category-wise analysis}

In this section, aggregated disclosure scores of intangible assets for each of the five categories i.e. human capital, external capital, internal capital, intangible assets scoresheet and mandatory disclosure requirements have been calculated. This is to determine the highest reported category out of the five categories mentioned above for the year 2003-04 and 2007-08. Table 5 shows the different categories of intangible assets disclosure index and score achieved by each category (in percentage) for both years.

\begin{tabular}{|l|l|l|}
\hline \multicolumn{1}{|c|}{ Categories } & $\mathbf{2 0 0 3 - 0 4}$ & $\mathbf{2 0 0 7 - 0 8}$ \\
\hline Human Capital & $29.89 \%$ & $26.61 \%$ \\
\hline External Capital & $37.90 \%$ & $35.83 \%$ \\
\hline Internal Capital & $16.97 \%$ & $17.68 \%$ \\
\hline $\begin{array}{l}\text { Intangible assets } \\
\text { scoresheet }\end{array}$ & $0.24 \%$ & $0.16 \%$ \\
\hline $\begin{array}{l}\text { Mandatory Disclosure } \\
\text { Requirements }\end{array}$ & $15 \%$ & $19.72 \%$ \\
\hline Total & $100 \%$ & $100 \%$ \\
\hline
\end{tabular}

Note: Disclosure percentages have been calculated using the weighted means

Table 5. Category wise Disclosures.

The results reveal external capital to be the most disclosed intangible assets category for both the years of the study. It has disclosure of $37.90 \%$ in the year 2003-04 and 35.83\% in the year 2007-08. The studies from Australia (Guthrie \& Petty, 2000); Ireland (Brennan, 2001); Italy (Bozzolan et al, 2003); South Africa (April et al, 2003); Malaysia (Goh \& Lim, 2004); Sri Lanka (Abeysekera \& Guthrie, 2005); Spain (Oliveras \& Kasperskaya, 2005); New Zealand (Wong \& Gardner, 2004) also revealed external capital to be most frequently reported intangible assets category. This dominance of external capital disclosures is due to the pivotal role of these disclosures in influencing stakeholder decisions. Therefore in order to show their edge over their competitors the companies might want to emphasize relations with their customers and other organizations, and promote their brand, which are all attributes of external capital. Guthrie and Petty (2000) explained skewness towards external disclosure because of increased emphasis in recent years on rationalizing distribution channels, reconfiguring a firm's value chain and reassessing customer value.

External capital category is closely followed by human capital category, which has disclosure of $29.89 \%$ in $2003-04$ and $26.61 \%$ in $2007-08$ The reason for high A study on intangible assets disclosure: An evidence from Indian companies 
disclosures of human capital could be that such disclosure is helpful for companies in attracting the talented employees and companies take pride in their high calibre management. The internal capital category has a disclosure of $16.97 \%$ in $2003-04$ which increased to $17.68 \%$ in 2007-08. Low disclosures in internal capital category as compared to external and human capital could be motivated by company's need to maintain its confidentiality on business processes, policies, systems etc over its competitors.

Further, the mandatory disclosure requirement category's share in overall disclosure has increased from $15 \%$ in $2003-04$ to $19.72 \%$ in 2007-08. This indicates increased awareness among Indian corporate houses regarding worth of intangible assets and their rising commitment to value these assets in their financial statements. The category intangible assets scoresheet has negligible disclosure score for both the years.

To summarize, the disclosure for categories of human capital, external capital \& intangible asset scoresheet has decreased and internal capital \& mandatory disclosure requirement category has increased in the year 2007-08 as compared to the year 2003-04.

\section{Part:II Company-wise analysis}

The company-wise disclosure score has been calculated by dividing the total weighted disclosure score obtained by a company during a particular year by the maximum score which a company could get (which is 54). The disclosure score has been calculated in percentages so as to make the disclosure of the companies comparable. An analysis of disclosure score of all the companies reveals that the reporting has improved in case of 191 companies, decreased in case of 35 companies and remained constant for 17 companies in the year 2003-04 and 2007-08. Tables 6 and 7 show the names and disclosure scores of the companies with highest and lowest disclosure scores for both the years of the study. Infosys Technologies Ltd., Satyam Computer services Ltd., Tata Steel Ltd., Max India Ltd., Reliance Industries Ltd., Larsen and Toubro Ltd., Dr. Reddy Ltd., Wipro Ltd. are among the top 10 companies, for disclosing their intangible assets for the years 2003-04 as well as 2007-08. HBL Power Systems Ltd., Ganesh Housing Corporation Ltd., Amtek Auto Ltd., Jyoti Structures Ltd., Bhushan Steel Ltd., JM Financial Ltd., Gujurat Fluorochemicals Ltd., Lanco Infratech Ltd. have zero 
disclosure score for the year 2003-04. The disclosure score for these companies significantly improved upto $22.22 \%$ in the year $2007-08$.

\begin{tabular}{|c|c|c|c|c|c|}
\hline \multirow{2}{*}{ Name of company } & \multicolumn{2}{|c|}{ 2003-04 } & \multicolumn{2}{|c|}{ 2007-08 } & \multirow{2}{*}{$\begin{array}{c}\text { Percentage } \\
\text { change in } \\
\text { disclosure } \\
\text { score in the } \\
\text { year } 2007-08 \\
\text { over 2003-04 }\end{array}$} \\
\hline & $\begin{array}{l}\text { Disclosure } \\
\text { score }(\%)\end{array}$ & Rank & $\begin{array}{l}\text { Disclosure } \\
\text { score (\%) }\end{array}$ & Rank & \\
\hline Infosys Technologies & 68.52 & 1 & 81.48 & 1 & 18.92 \\
\hline Hero Honda Motors & 53.7 & 2 & 33.33 & 77 & -37.93 \\
\hline Satyam Computer Services & 51.85 & 3 & 61.11 & 2 & 17.86 \\
\hline Tata Steel & 46.3 & 4 & 53.7 & 5 & 16 \\
\hline Tata Power & 44.44 & 5 & 42.59 & 23 & -4.17 \\
\hline Dabur India & 44.44 & 5 & 42.59 & 23 & -4.17 \\
\hline Max India & 44.44 & 5 & 53.7 & 5 & 20.83 \\
\hline ICICI Bank & 40.74 & 8 & 38.89 & 39 & -4.55 \\
\hline Indian Hotels Co. & 40.74 & 8 & 38.89 & 39 & -4.55 \\
\hline Asian Paints & 40.74 & 8 & 22.22 & 163 & -45.45 \\
\hline Voltas & 40.74 & 8 & 38.89 & 39 & -4.55 \\
\hline Asahi India Glass & 40.74 & 8 & 33.33 & 77 & -18.18 \\
\hline 3I Infotech & 40.74 & 8 & 40.74 & 33 & 0 \\
\hline Reliance Industries & 38.89 & 14 & 50 & 9 & 28.57 \\
\hline Larsen \& Toubro & 38.89 & 14 & 57.41 & 3 & 47.62 \\
\hline Dr. Reddy & 38.89 & 14 & 55.56 & 4 & 42.86 \\
\hline
\end{tabular}

Table 6. Company-wise Disclosure (high disclosure companies).

\begin{tabular}{|l|c|c|c|c|c|}
\hline \multirow{2}{*}{ Name of company } & \multicolumn{2}{|c|}{$2003-04$} & \multicolumn{2}{c|}{ 2007-08 } & $\begin{array}{c}\text { Percentage } \\
\text { change in } \\
\text { disclosure } \\
\text { score in the } \\
\text { year 2007-08 } \\
\text { over 2003-04 }\end{array}$ \\
\cline { 2 - 6 } & $\begin{array}{c}\text { Disclosure } \\
\text { score (\%) }\end{array}$ & Rank & $\begin{array}{c}\text { Disclosure } \\
\text { score (\%) }\end{array}$ & Rank & 2200 \\
\hline KS Oils & 1.85 & 227 & 42.59 & 23 & 1300 \\
\hline ICSA (India) & 1.85 & 227 & 25.93 & 136 & 300 \\
\hline Era Infra Engineering & 1.85 & 227 & 7.41 & 229 & 100 \\
\hline Ahmednagar Forgings & 1.85 & 227 & 3.7 & 237 & 200 \\
\hline Ratnamani Metals \& Tubes & 1.85 & 227 & 5.56 & 236 & 100 \\
\hline Ruchi Infrastructure & 1.85 & 227 & 3.7 & 237 & NA \\
\hline Lanco Infratech & 0 & 236 & 22.22 & 163 & NA \\
\hline Gujarat Fluorochemicals & 0 & 236 & 20.37 & 174 & NA \\
\hline JM Financial & 0 & 236 & 22.22 & 163 & NA \\
\hline Bhushan Steel & 0 & 236 & 22.22 & 163 & NA \\
\hline Jyoti Structures & 0 & 236 & 7.41 & 229 & NA \\
\hline Amtek India & 0 & 236 & 9.26 & 224 & \\
\hline
\end{tabular}

A study on intangible assets disclosure: An evidence from Indian companies 


\begin{tabular}{|l|l|l|l|l|l|} 
Ganesh Housing Corpn. & 0 & 236 & 3.7 & 237 & NA \\
\hline HBL Power Systems & 0 & 236 & 11.11 & 217 & NA \\
\hline
\end{tabular}

Table 7. Company-wise Disclosure (low disclosure companies).

The above table reveals that the range of disclosure score of the companies varies from zero to $68.52 \%$ for the year $2003-04$ and from $1.85 \%$ to $81.48 \%$ for the year 2007-08. Infosys Technologies has occupied first position for both years of the study. Infosys Technologies was the first Indian company to incorporate additional disclosures like Intangible assets scoresheet, Brand Valuation, Human Resource Accounting in its annual reports. Most of the intangible assets information is given in Management Discussion and Analysis section of the annual report. In addition to the above, the average number of attributes reported per company (total number of attributes reported by sample companies divided by total number of companies) is 7 in the year 2003-04 and 10 in the year 2007-08. Also the maximum and the minimum number of attributes reported for any one company is $23 \& 0$ for the year 2003-04 and $26 \& 1$ for the year 2007-08 respectively.

Further table 8 gives the classification of companies according to their disclosure percentages for the year 2003-04 and 2007-08.

\begin{tabular}{|c|c|c|}
\hline \multirow{2}{*}{ Disclosure Percentages } & \multicolumn{2}{|c|}{ Number of companies } \\
\cline { 2 - 3 } & $\mathbf{2 0 0 3 - 0 4}$ & $\mathbf{2 0 0 7 - 0 8}$ \\
\hline $\mathbf{0 - 2 0}$ & 149 & 70 \\
\hline $\mathbf{2 0 - 4 0}$ & 81 & 135 \\
\hline $\mathbf{4 0 - 6 0}$ & 12 & 36 \\
\hline $\mathbf{6 0 - 8 0}$ & 1 & 1 \\
\hline Above 80 & 0 & 1 \\
\hline $\mathbf{N}$ & 243 & 243 \\
\hline
\end{tabular}

Table 8. Classification of Companies According to the Disclosure Percentages.

Table 8 exhibits that a large number of companies have a disclosure score between 0-20 percent for the year 2003-04. While in the year 2007-08, the number of companies having disclosure score between 0-20 percent has declined and shifted to higher disclosure score range of 20-40 percent. The companies whose disclosure score remarkably improved in the year 2007-08 over the year 2003-04 are KS Oils Ltd $(1.85 \%$ to $42.59 \%)$, ICSA Ltd ( $1.85 \%$ to $25.93 \%)$, Binani Cement Ltd. $(1.85 \%$ 
to $25.93 \%)$, Asian Star Co. Ltd. (1.85\% to $20.37 \%)$ etc. This shift marks the companies' consistent efforts to improve their intangible assets disclosures.

Table 8 also exhibits that number of companies disclosing within the range of $40-$ 60 percent have also increased from 12 to 36 . While none of the companies is disclosing in "above 80" range in the year 2003-04, Infosys Technologies is the first company to break into this range for the year 2007-08.

The intangible assets disclosure practices of companies on the basis of industry classification like automotive, banking and financial services, software and IT, media and telecommunication etc was also analyzed. The descriptive statistics of different industries i.e. mean disclosure score, standard deviation and range have been presented in table 9 for the years 2003-04 and 2007-08 respectively.

\begin{tabular}{|c|c|c|c|c|c|c|c|c|c|}
\hline \multirow{3}{*}{ Name of industry } & \multirow{3}{*}{$\mathbf{N}$} & \multicolumn{8}{|c|}{ Disclosure Score (in percent) } \\
\hline & & \multicolumn{4}{|c|}{ 2003-04 } & \multicolumn{4}{|c|}{ 2007-08 } \\
\hline & & Mean & SD & Min & Max & Mean & SD & Min & Max \\
\hline Agri input and tobacco & 11 & 17.51 & 8.82 & 3.70 & 31.48 & 25.25 & 11.78 & 1.85 & 42.59 \\
\hline Automotive & 15 & 21.85 & 14.36 & 0.00 & 53.70 & 27.65 & 10.13 & 9.26 & 44.44 \\
\hline $\begin{array}{l}\text { Banking \& financial } \\
\text { services }\end{array}$ & 16 & 15.63 & 11.43 & 0.00 & 40.74 & 27.04 & 9.57 & 9.26 & 38.89 \\
\hline $\begin{array}{l}\text { Capital goods, industrial } \\
\text { and engg products }\end{array}$ & 29 & 16.48 & 10.41 & 0.00 & 40.74 & 24.71 & 10.79 & 3.70 & 48.15 \\
\hline Construction \& electricity & 26 & 13.39 & 12.43 & 0.00 & 44.44 & 26.35 & 14.44 & 3.70 & 57.41 \\
\hline $\begin{array}{l}\text { Consumer goods, } \\
\text { electronics, durables } \\
\text { \& FMCG }\end{array}$ & 26 & 18.38 & 14.35 & 1.85 & 44.44 & 27.35 & 12.84 & 3.70 & 46.30 \\
\hline $\begin{array}{l}\text { Drugs \& } \\
\text { pharmaceuticals }\end{array}$ & 31 & 22.64 & 10.70 & 3.70 & 42.59 & 31.30 & 10.80 & 14.81 & 55.56 \\
\hline $\begin{array}{l}\text { Media \& } \\
\text { telecommunication }\end{array}$ & 8 & 18.98 & 8.73 & 3.70 & 29.63 & 30.32 & 10.19 & 12.96 & 44.44 \\
\hline $\begin{array}{l}\text { Petrochemicals, } \\
\text { chemicals \& plastic } \\
\text { products }\end{array}$ & 12 & 22.07 & 14.57 & 0.00 & 51.85 & 30.86 & 13.71 & 9.26 & 53.70 \\
\hline Software, IT \& ITES & 28 & 28.04 & 11.74 & 1.85 & 61.11 & 34.59 & 13.35 & 14.81 & 79.63 \\
\hline $\begin{array}{l}\text { Steel \& other metals } \\
\text { and minerals }\end{array}$ & 17 & 13.51 & 12.74 & 0.00 & 46.30 & 24.07 & 15.42 & 3.70 & 53.70 \\
\hline Textiles \& apparel & 8 & 15.51 & 7.47 & 3.70 & 24.07 & 28.24 & 6.16 & 16.67 & 37.04 \\
\hline $\begin{array}{l}\text { Transport, tourism, } \\
\text { hotels \& other } \\
\text { diversified }\end{array}$ & 16 & 15.28 & 10.40 & 3.70 & 40.74 & 22.69 & 12.31 & 1.85 & 44.44 \\
\hline
\end{tabular}

Table 9. Industry Wise Disclosure Score. 


\section{Intangible Capital}

Intangible Capital, 2011 - 7(1): 1-30 - ISSN: 1697-9818 doi:10.3926/ic.2011.v1n7.p1-30

Table 9 shows that the companies belonging to different industries have variations in their mean disclosure score for both years of the study. It clearly shows that the mean disclosure score of software industry is highest for both years of the study. The score is $28.04 \%$ in $2003-04$ and this increased to $34.59 \%$ in the year $2007-08$. Variations and range has also increased in the year 2007-08 over 2003-04. The mean disclosure score of drugs and pharmaceutical industry has increased from $22.64 \%$ in the year $2003-04$ to $31.30 \%$ in year $2007-08$. This industry occupies second highest mean disclosure score for both years of the study. A slight increase in variations and range is also noticed for this industry in the year 2007-08 as compared to 2003-04.

The disclosure regarding intangible assets has improved for almost all the industries for the year 2007-08 over the year 2003-04.This might be inspired by higher investor expectation from all the companies belonging to different industries and increased awareness of the significance of intangible assets amongst the companies.

The finding that the mean disclosure score of software, IT and ITES industry is highest as compared to other industries is not surprising. Firms in this knowledge based industry need to be more proactive as they face greater competition and they often have to rely on immutable intangibles that are difficult for competitors to imitate (Teece, 2000). The high mean disclosure score for Drugs and pharmaceutical industry could be motivated by the need to recognize the research activities and patents in this industry.

\section{Inter-period comparison of intangible assets disclosure}

In addition to the above, the intangible assets disclosure pattern for both the years of the study has also been analyzed with the help of paired sample t-test. It was applied to find out any significant difference in the intangible assets reporting of the companies in the year 2003-04 and 2007-08. Table 10 presents the results of this test.

Table 10 depicts that the difference between mean disclosure score of intangible assets for the year 2003-04 and 2007-08 is significant at one percent level. Thus, the companies in India on an average disclose more on intangible assets in 200708 than in 2003-04 and such difference is significant. An upward trend in intangible 
assets disclosure indicates increasing awareness about the significance of intangible assets reporting among Indian companies.

\begin{tabular}{|c|l|l|l|l|l|l|}
\hline Year & $\begin{array}{c}\text { Number of } \\
\text { Companies }\end{array}$ & Mean & $\begin{array}{c}\text { Std. } \\
\text { Deviation }\end{array}$ & $\begin{array}{c}\text { Std. Error } \\
\text { Mean }\end{array}$ & t & $\begin{array}{c}\text { Sig. (2- } \\
\text { tailed) }\end{array}$ \\
\hline $\mathbf{2 0 0 3 - 0 4}$ & 243 & 18.84 & 12.451 & 0.799 & \multirow{2}{*}{14.21} & 0 \\
\hline $\mathbf{2 0 0 7 - 0 8}$ & 243 & 28.09 & 12.452 & 0.799 & \\
\hline
\end{tabular}

Table 10. Results of paired sample t-test.

\section{Conclusion}

Based on the above discussions and analysis of the intangible assets disclosure practices of selected Indian companies made on the basis of attribute-wise and company-wise disclosures, the following conclusions can be drawn:

- The level of intangible assets disclosure is low in case of Indian firms, though it has improved in the year 2007-08 as compared to the year 200304 (Reference table 3).

- Out of the five categories of the intangible assets disclosure index, external capital is the most reported category for both the years of the study. It has a disclosure score of $37.90 \%$ and $35.83 \%$ in the years $2003-04$ and $2007-$ 08 respectively. This could be due to the pivotal role of these disclosures in influencing stakeholder decisions. In order to prove their edge over their competitors the companies might want to emphasize on relations with their distributors, business associates, customers, society and other organizations, and promote their brand, which are all attributes of external capital.

- In all the five categories, the attributes most reported are "number of employees" (human capital), "markets \& market share" (external capital), "business collaborations" (external capital), "research projects" (internal capital), "intangible assets valuation" (mandatory disclosure requirement) and "details of amortization rates, method and carrying amount at beginning and end of period" (mandatory disclosure requirement). This 


\section{Intangible Capital}

Intangible Capital, 2011 - 7(1): 1-30 - ISSN: 1697-9818 doi:10.3926/ic.2011.v1n7.p1-30

implies that the companies in India tend to report mostly those attributes of intangible assets which are either mandatory or the disclosure of which can create competitive advantage for them ( e.g. business collaborations, projects, market share).

- Reporting of intangible assets is unorganized and unsystematic. This is due to the lack of an established, and generally accepted framework for reporting these assets. It may also be the case that companies are genuinely committed to the idea of managing and developing their intangible assets but do not have, or are not aware of the benefits from its disclosure to stakeholders. Some companies view the development of intangible assets as being an internal management issue and therefore outside the scope of the annual report (Guthrie \& Petty, 2000).

- The accounting standards on intangible assets available worldwide require the disclosure of such intangible assets that can be valued in monetary term and thus can be shown in the balance sheet of a company. The research on the other side takes a broader view of intangible assets to include their qualitative description also. So there is a need to develop an index of intangible assets disclosure to incorporate both quantitative as well as qualitative description of intangible assets.

- The lack of established and generally accepted intangible assets reporting framework has contributed to unorganized and unsystematic reporting of these assets.

- Analysis of qualitative and quantitative nature of disclosure shows that the intangible assets reporting is mainly qualitative. Though in the year 200708 there is $\mathrm{s}$ shift in trend towards quantitative disclosures over the year 2003-04.

- The mean disclosure score of intangible assets for 243 companies improved in 2007-08 over 2003-04 and these differences are significant at $1 \%$ level of significance. This implies that with the passage of time, the Indian companies are becoming conscious of the potential benefits of disclosing intangible assets in their annual reports. 


\section{Intangible Capital}

Intangible Capital, 2011 - 7(1): 1-30 - ISSN: 1697-9818 doi:10.3926/ic.2011.v1n7.p1-30

- Most of the intangible assets disclosures were found in the Management Discussion and Analysis (MDA) section of an annual report.

- Infosys Technologies Ltd has the highest intangible assets disclosure score for both years of the study (2003-04: 68.52\%, 2007-08: 81.48\%). Satyam Computer Services Ltd., Tata steel Ltd., Max India Ltd., Reliance Industries Ltd., Larsen and Toubro Ltd., Dr.Reddy Ltd., Wipro Ltd., are few other companies with high disclosure scores for both the years of the study. These companies belong to the industries where intangible assets play a crucial role in their growth.

- Software industry has highest mean disclosure score of intangible assets in India. The possible reason for this could be the paramount importance of intangible assets to this industry and high overseas stakeholders' expectations.

\section{References}

ABEYSEKERA, I.; GUTHRIE J. (2005). An Empirical Investigation of Annual Reporting Trends of Intellectual Capital in Sri Lanka. Critical Perspectives on Accounting, 16(2): 151-163.

doi:10.1016/S1045-2354(03)00059-5

ALI, M.; KHAN, H.; FATIMA, Z.K. (2008). Intellectual Capital Reporting Practices: A Study on Selected Companies in Bangladesh. Journal of Business Studies, 29(1): 81-104.

APRIL, K.A.; BOONIA, P.; DEGLON, D. (2003). Intellectual Capital measurement and reporting: establishing a practice in South African inning. Journal of Intellectual Capital, 4(2):165-180.

doi: $10.1108 / 14691930310472794$

BONTIS, N.; CROSSAN, M.; HULLAND, J. (2002). Managing an Organizational Learning System by Aligning Stocks and Flows. Journal of Management Studies, 39(4); 437-469.

doi: $10.1111 / 1467-6486 . t 01-1-00299$ 


\section{Intangible Capital}

Intangible Capital, 2011 - 7(1): 1-30 - ISSN: 1697-9818 doi:10.3926/ic.2011.v1n7.p1-30

BONTIS, N. (2003). Intellectual Capital disclosures in Canadian Corporations. Journal of Human Resource Costing and Accounting, 7(1): 9-20.

doi:10.1108/eb029076

BOTOSAN, C. (1997). Disclosure level and the cost of equity capital. Accounting Review, 72(3): 323-349.

BOZZOLAN, S.; FAVOTTO, F.; RICCERI, F. (2003). Italian annual intellectual capital disclosure. Journal of Intellectual Capital, 4(4): 543-558.

doi: $10.1108 / 14691930310504554$

BRENNAN, N. (2001). Reporting intellectual Capital in annual reports: evidence from Ireland. Accounting, Auditing and Accountability Journal, 14(4): 423-436. doi:10.1108/09513570110403443

EDVINSSON, L.; MALONE, M.S. (1997). Intellectual Capital: Realizing Your Company's True Value by Finding Its Hidden Brainpower. New York: Harper Business.

FASB (1978). Statements of Financial Accounting Concepts - 1 on Objectives of Financial Reporting by Business Enterprises. http://www.fasb.org/cs/BlobServer?blobcol=urldata\&blobtable=MungoBlobs\&blob key=id\&blobwhere $=1175820899258 \&$ blobheader $=$ application $\% 2 F p d f$

GARCÍA-PARRA, M.; SIMO, P.; MUNDET, J.; GUZMAN, J. (2004). Intangibles: assets and liabilities. Intangible Capital, 0(3): 70-86.

GARCÍA-PARRA, M.; SIMO, P.; SALLAN, J.M.; MUNDET, J. (2009). Intangible liabilities: beyond models of intellectual assets. Management Decision, 47(5): 819-830.

doi: $10.1108 / 00251740910960141$

GERPOTT, T.J.; THOMAS, S.E.; HOFFMANN, A.P. (2008). Intangible asset disclosure in the telecommunications industry. Journal of Intellectual Capital, 9(1): 37-61. doi: $10.1108 / 14691930810845795$

GOH, P.; LIM, K. (2004). Disclosing intellectual capital in company annual reports. Evidence from Malaysia. Journal of Intellectual Capital, 5(3): 500-510. doi:10.1108/14691930410550426 
GUTHRIE, J.; PETTY, R. (2000). Intellectual Capital: Australian annual reporting practices. Journal of Intellectual Capital, 1(3): 241-251.

doi: $10.1108 / 14691930010350800$

GUTHRIE, J.; PETTY, R.; JOHANSON, U. (2001). Sunrise in the Knowledge economy: Managing, measuring and reporting intellectual capital. Accounting, Auditing and Accountability Journal, 14(4): 365-382.

doi: $10.1108 /$ EUM0000000005869

GUTHRIE, J.; PETTY, R.; YONGVANICH, K.; RICCERI, F. (2004). Using Content Analysis as a research method to inquire into intellectual capital reporting. Journal of Intellectual Capital, 5(2): 282-293.

doi: $10.1108 / 14691930410533704$

GUTHRIE, J.; PETTY, R.; RICCERI, F. (2006). The voluntary reporting of intellectual capital: Comparing evidence from Hong Kong and Australia. Journal of Intellectual Capital, 7(2): 254-271.

doi: $10.1108 / 14691930610661890$

IFAC (1998). Measurement and Management of Intellectual Capital. New York, NY: IFAC.

KAMATH, B. (2008). Intellectual Capital Disclosure in India: content analysis of "Teck" firms. Journal of Human Resource Costing and Accounting, 12(3): 213224.

doi:10.1108/14013380810919859

LEV, B. (2001). Intangibles. Management, Measurement, and Reporting. Washington D.C: The Brookings Institution.

MECA, E.G.; MARTINEZ, I., (2005). Assessing the quality of disclosure on intangibles in the Spanish Capital Market. European Business Review, 17(4): 305313.

doi: $10.1108 / 09555340510607352$

MERITUM (2000). Guidelines for the measurement and disclosure of intangibles. http://www.fek.su.se/home/bic/meritum/download/Guidelines.rtf, consulted: 2007-October $15^{\text {th }}$. 


\section{Intangible Capital}

Intangible Capital, 2011 - 7(1): 1-30 - ISSN: 1697-9818 doi:10.3926/ic.2011.v1n7.p1-30

MILNE, M.; ADLER, R. (1999). Exploring the reliability of social and environmental disclosures content analysis. Accounting, Auditing \& Accountability Journal, 12(2): 237-256.

\section{doi: $10.1108 / 09513579910270138$}

OLIVEIRA, L.; RODRIGUES, L.L.; CRAIG, R. (2006). Firm-Specific determinants of intangibles reporting: evidence from the Portuguese stock market. Journal of Human Resource Costing and Accounting, 10(1): 11-33.

doi:10.1108/14013380610672657

OLIVERAS, E.; KASPERSKAYA, Y. (2005). Reporting Intellectual Capital in Spain. http://papers.ssrn.com/sol3/papers.cfm?abstract id=848664, consulted: 2009December $15^{\text {th }}$.

ORDÓÑEZ DE PABLOS, P. (2005). Intellectual capital reports in India: lessons from a case study. Journal of Intellectual Capital, 6(1): 141-149.

doi: $10.1108 / 14691930510574717$

STEENKAMP, N. (2007). Intellectual Capital Reporting in New Zealand: refining content analysis as a research method. PhD Thesis, Auckland University of Technology, Auckland (unpublished).

SUJAN, A.; ABEYSEKERA, I. (2007). Intellectual Capital Reporting practices of the top Australian firms. Australian Accounting Review, 17(2): 71-83.

doi:10.1111/j.1835-2561.2007.tb00445.x

SVEIBY, K.E. (1997). The New Organisational wealth. Managing and measuring Knowledge-Based assets. New York, NY: Berrett-Koehler.

TEECE, D.J. (2000). Strategies for Managing Knowledge Assets: The role of Firm Structure and Industrial Context. Long Range Planning, 33: 35-54. doi:10.1016/S0024-6301(99)00117-X

VERGAUWEN, P.G.M.C.; ALEM, F.J.C. (2005). Annual report IC disclosures in the Netherlands, France and Germany. Journal of Intellectual Capital, 6(1): 89-104. doi:10.1108/14691930510574681 
WONG, M.; GARDENER, C. (2004). Intellectual Capital Disclosure: New Zealand evidence. Journal of Economic Literature, http://www.afaanz.org/web2005/papers/gardnerc.pdf, consulted: 2008-July 31.

WOODROCK, J.; WHITING, R.H. (2009). Intellectual capital disclosures by Australian companies, accepted for presentation at the AFAANZ Conference. http://eprints.otago.ac.nz/859/1/03 2009 Ros Whiting.pdf, consulted: 2009November 29.

\title{
Appendix A
}

\section{Intangible asset disclosure index}

\section{Human capital}

\author{
Employees- \\ -Number \\ -Gender \\ -Professional qualification \& Experience \\ -Compensation \\ Training \& Development \\ Work related knowledge \\ Entrepreneurial Spirit \\ Human resource accounting
}

\section{External capital}

Brands and their descriptions

Brand Valuation

Distribution channels

Market share, markets

Business collaboration

Customer satisfaction

Customer information

Social activities

\section{Internal capital}

Research projects

Networking and information Systems

Organization Structure

Corporate culture

Patents

Copyrights

Trademarks

\section{Intangible assets scoresheet}

\section{Requirements of accounting standard-26}


Distinguish between internally generated and other intangible assets Details of amortization rates, method and carrying amount at beginning and end of period Classification of intangible assets

Other disclosures like pledging information, reasons for amortizing over more than maximum number of years etc

Intangible assets Valuation

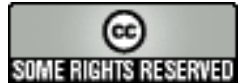

Article's contents are provided on a Attribution-Non Commercial 3.0 Creative commons license. Readers are allowed to copy, distribute and communicate article's contents, provided the author's and Intangible Capital journal's names are included. It must not be used for commercial purposes. To see the complete licence contents, please visit http://creativecommons.org/licenses/by-nc/3.0/es/ 